\title{
Pilomatricoma: calcifying epithelioma of Malherbe
}

\section{Pilomatricoma: epitelioma calcificado de Malherbe}

\author{
Rebeca Paohwa Liu da \\ FONSECA $^{1}$ \\ José de Souza Andrade \\ FILHO $^{2}$ \\ Izabella Costa Araujo ${ }^{3}$ \\ Aloísio Ferreira da Silva \\ FILHO $^{4}$ \\ Nárlei Amarante Pereira ${ }^{4}$ \\ Eduardo Eustáquio Salera \\ de Carvalho ${ }^{4}$ \\ José Carlos Ribeiro \\ Resende Alves 5
}

This study was performed at the Plastic Surgery Clinic of the Hospital Felício Rocho,

Belo Horizonte, MG, Brazil.

Submitted to SGP (Sistema de Gestão de Publicações/Manager Publications System) of RBCP (Revista Brasileira de Cirurgia

Plástica/Brazilian Journal of Plastic Surgery).

Article received: September 2, 2012 Article accepted: October 21, 2012

\begin{abstract}
Background: Pilomatricoma (calcifying epithelioma of Malherbe) represents approximately $1 \%$ of all benign skin tumors. The aim of this retrospective study was to review the clinical and histopathological characteristics of this lesion in patients presenting to the Departments of Plastic Surgery and Pathology of a general hospital. Methods: Data regarding 68 lesions in 56 patients were reviewed. All patients underwent surgical excision of the tumors. The medical records were reviewed for gender, age, lesion location and size, preoperative diagnosis, recurrence, and particular histopathological characteristics. Results: Thirty-one patients (55.4\%) were male and 25 (44.6) female. The lesions were distributed in the face (42.4\%), upper limbs (19.7\%), trunk (13.6\%), lower limbs (12.1\%), neck $(9.1 \%)$, and scalp (3.1\%). In one patient, the condition recurred following the first surgical treatment. Another patient had multiple presentation of her lesions, that appeared in several locations and five different occasions. A third patient was diagnosed with proliferating pilomatricoma. All neoplasms were benign lesions. Pilomatricomas were clinically diagnosed by the surgeons only in $19.7 \%$ of the cases. Conclusions: Pilomatricoma should be considered in the differential diagnosis of nodules, especially those on the head and neck. Careful clinical examination and familiarity with the condition may lead to accurate diagnosis and appropriate treatment.
\end{abstract}

Keywords: Pilomatrixoma. Skin neoplasms. Hair diseases.

\section{RESUMO}

Introdução: Pilomatricoma (epitelioma calcificante de Malherbe) representa cerca de 1\% dos tumores benignos de pele. O objetivo deste estudo retrospectivo é rever as características clínicas e histopatológicas dessa lesão em pacientes tratados nos Departamentos de Cirurgia Plástica e Anatomia Patológica de um hospital geral. Método: Dados relacionados a 68 lesões, presentes em 56 pacientes, foram revisados. Todos os pacientes foram submetidos a excisão cirúrgica dos tumores. Os seguintes aspectos foram estudados: gênero, idade, localização e tamanho das lesões, diagnóstico pré-operatório, recorrência e características peculiares à histopatologia. Resultados: Trinta e um pacientes eram do sexo masculino $(55,4 \%)$ e 25 , do feminino $(44,6 \%)$. As lesões estavam localizadas na face $(42,4 \%)$, membros superiores $(19,7 \%)$, tronco $(13,6 \%)$, membros inferiores $(12,1 \%)$, pescoço $(9,1 \%)$ e couro cabeludo $(3,1 \%)$. Em um paciente, foi observada recorrência após o primeiro tratamento cirúrgico. Outra paciente apresentou lesões em vários locais, em cinco ocasiões diferentes. Um terceiro paciente teve o diagnóstico de pilomatricoma proliferante. Todos os tumores eram benignos. O diagnóstico clínico de pilomatricoma foi realizado pelo cirurgião em ape-

1. Plastic surgeon, specialist member of the Sociedade Brasileira de Cirurgia Plástica (Brazilian Society of Plastic Surgery - SBCP), member of the clinical staff at the Department of Plastic Surgery of the Hospital Felício Rocho and of the Instituto de Cirurgia Plástica Avançada, Belo Horizonte, MG, Brazil.

2. Professor of Pathology at the Faculdade de Ciências Médicas de Minas Gerais, head of the Department of Pathological Anatomy of the Hospital Felício Rocho, Belo Horizonte, MG, Brazil.

3. Aspiring member in training of the SBCP, resident physician of the Department of Plastic Surgery of the Hospital Felício Rocho, Belo Horizonte, MG, Brazil.

4. Plastic surgeon, full member of the SBCP, member of the clinical staff of the Department of Plastic Surgery of the Hospital Felício Rocho and of the Instituto de Cirurgia Plástica Avançada, Belo Horizonte, MG, Brazil.

5. Doctor in Surgery by the Universidade Federal de Minas Gerais, full member of the SBCP, Professor of Surgical and Anesthetic Techniques at the Faculdade de Medicina da Universidade de Itaúna, member of the clinical staff of the Department of Plastic Surgery of the Hospital Felício Rocho and of the Instituto de Cirurgia Plástica Avançada, Belo Horizonte, MG, Brazil. 
nas 19,7\% dos casos. Conclusões: Pilomatricomas devem ser considerados no diagnóstico diferencial, especialmente dos nódulos de cabeça e pescoço. Exame clínico cuidadoso e conhecimento da lesão favorecem o diagnóstico preciso e, portanto, o tratamento adequado.

Descritores: Pilomatrixoma. Neoplasias cutâneas. Doenças do cabelo.

\section{INTRODUCTION}

In 1880, Malherbe and Chenantais ${ }^{1}$, in France, published the paper "Note sur l'épitheliome calcifié des glandes sebacées", supposing the lesions were derived from sebaceous glands. Since then, the lesion received the name of "calcifying epithelioma of Malherbe". In 1922, Dubreuilh \& Cazenave $^{2}$ described the histopathological features of this tumor, including islands of epithelial cells and shadow cells. In 1961, Forbis \& Helwig ${ }^{3}$ introduced the term pilomatrixoma, defining the neoplasm as a hair cell derived lesion and avoiding the word epithelioma, that has connotation of malignancy. The expression was further modified to pilomatricoma because of phonetic reasons ${ }^{4}$. In 1966, Hashimoto et al. ${ }^{5}$ related histochemical and electron microscopic studies of the lesion, considering it as being derived from primitive basal cells of epidermis that differentiate as hair matrix cells.

Clinically, pilomatricomas are well circumscribed, solitary, painless, subcutaneous tumors. The lesions grow slowly, without itching or other symptoms. The skin over the neoplasm may present normal appearance or changes in color from pale to red or bluish. The lesion is fixed to the overlying skin, but mobile in relation to deep planes. Epithelial thinning or even ulceration may occur. Pilomatricomas show predilection for the face, but may be present in any region of the body, except in the palms or soles ${ }^{6}$.

Pilomatricoma is diagnosed by clinical examination. The consistency of the lesion varies considerably, depending on the degree of calcification ${ }^{7}$. Ultrasound examination may be helpful in diagnosis. Classical ultrasound features are a totally calcified nodule or a hypoechoic nodule with internal calcified foci. New ultrasound patterns were reported and the lesion may exhibit five types: partially calcified, completely calcified, complex/mixed-shaped, pseudocystic, and pseudotumoral ${ }^{7}$. Computed tomography examination should be considered for patients who have large tumors on the face, particularly to differentiate between preauricular pilomatricomas and parotid gland neoplasms ${ }^{8}$.

Histopathologic examination shows nodules with sharp demarcation, surrounded by a fibrous capsule, located in the reticular dermis and extending to the subcutaneous fat. The cells are arranged in islands with a circular configuration, with basaloid cells in the periphery and anucleated shadow cells in the center. shadow cells, also termed ghost cells, evolve from basaloid cells and are dead cells that preserve cellular shape, with a central unstained area that corresponds to the lost nucleus. Transitional cells are observed between the basaloid cells and the ghost cells. Calcification is mainly seen in ghost cells regions. Foreign body reactions, characterized by the presence of giant cells, are seen in areas of keratinized debris ${ }^{3,8}$.

The purpose of this retrospective study was to review the clinical and histopathological aspects of pilomatricoma in patients seen at the Departments of Plastic Surgery and Pathological Anatomy of a general hospital.

\section{METHODS}

Data of 56 patients, corresponding to 68 pilomatricomas treated surgically between April 2003 and July 2012 were reviewed with the aim of obtaining information regarding gender, age, tumor location and size, preoperative diagnosis, histopathological characteristics, and findings during the follow-up period.

Twenty-six patients (with a total of 37 lesions) underwent surgery and were postoperatively followed at the Plastic Surgery Clinic of the Hospital Felício Rocho (Belo Horizonte, MG, Brazil).

Thirty patients (with a total of 31 lesions) were treated elsewhere or in other clinics of the same hospital, but the surgical samples were examined by the department of anatomic pathology of the same hospital.

All samples were stained with hematoxylin and eosin. Only the patients treated in the Plastic Surgery Clinic underwent follow-up.

The data were entered into a Microsoft Office Excel spreadsheet. Graphs were created using the Sigma Plot software, version 10.0 (Systat, 2006).

The relevant literature was reviewed using the terms pilomatricoma, pilomatrixoma, calcifying epithelioma of Malherbe, epitelioma calcificado de Malherbe, and epitelioma calcificante de Malherbe as keywords.

\section{RESULTS}

Thirty-one $(55.4 \%)$ of the 56 patients were male and 25 (44.6) female, yielding a male:female ratio of 1.24:1 (Figure 1). The patient ages at the time of surgery were 
1-71 years (mean, 26.5 years). The tumors occurred most commonly in the first and second decades of life, accounting for $59.3 \%$ of the cases, and were distributed in a progressively descending pattern among the other age groups. The peak incidence occurred before the age of 10 years. The distribution according to age is shown in Figure 2. Age was not recorded in 2 cases.

In 2 cases of the 68 lesions, the samples were processed without recording information regarding lesion location. Of the remaining cases, 28 (42.4\%) occurred on the face, 13 (19.7\%) on the upper limbs, $9(13.6 \%)$ on the trunk, $8(12.1 \%)$ on the lower limbs, $6(9.1 \%)$ on the neck, and $2(3.1 \%)$ on the scalp (Figure 3).

Lesion size ranged from 0.2 to $1.3 \mathrm{~cm}$ (mean, $0.6 \mathrm{~cm}$ ). In 3 cases, information regarding lesion size was not recorded by the pathologist. In $13(19.7 \%)$ of the 66 lesions, the correct clinical diagnosis was suspected by the surgeon. The most frequent misdiagnosis were carcinoma (12.1\%) and epidermoid cyst $(9.1 \%)$. In 2 cases, the suspected diagnosis was not recorded by the clinician. One female patient had recurrence of her superciliary lesion 3 months after surgery. Also, a girl, who has the clinical diagnosis of Kabuki Syndrome, had a total of 8 lesions removed from face (4),

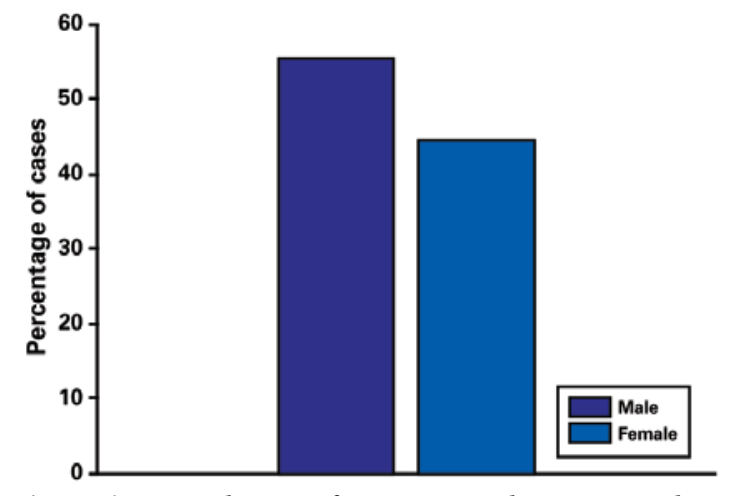

Figure 1 -Distribution of patients in relation to gender.

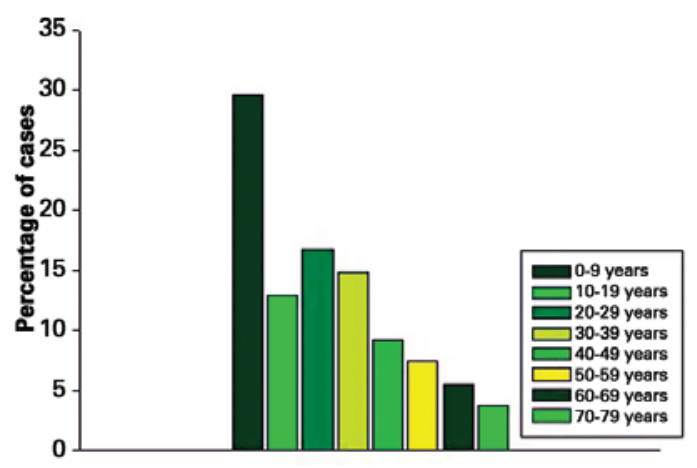

Figure 2 - Patient distribution by age. trunk (3) and lower limb (1) at 5, 7, 9, 11 and 14 years old. Finally, a patient with a lesion on the trunk was diagnosed with proliferating pilomatricoma (Figures 4 and 5).

The histopathological characteristics of this neoplasm are shown in Figures 6 to 8. A circular pattern of cellular distribution can be observed, with basaloid cells in the periphery and anucleated shadow cells, also known as ghost cells, in the center.

The evolution of basaloid cells into ghost cells is characterized by the loss of their nuclei. Figures 7 and 8 show a more detailed image of this feature.

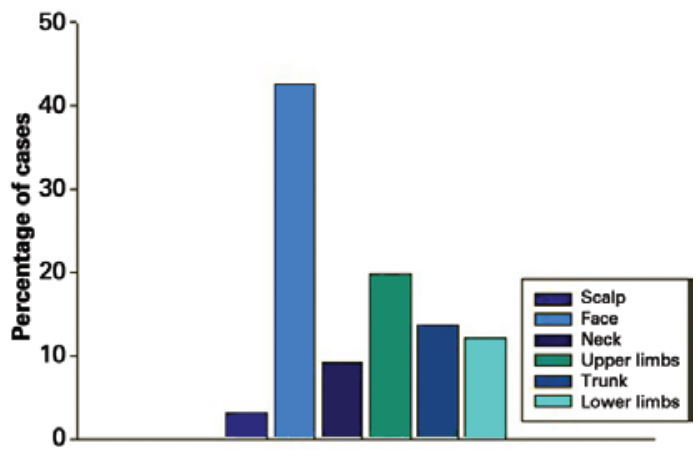

Figure 3 - Patients distribution by location.
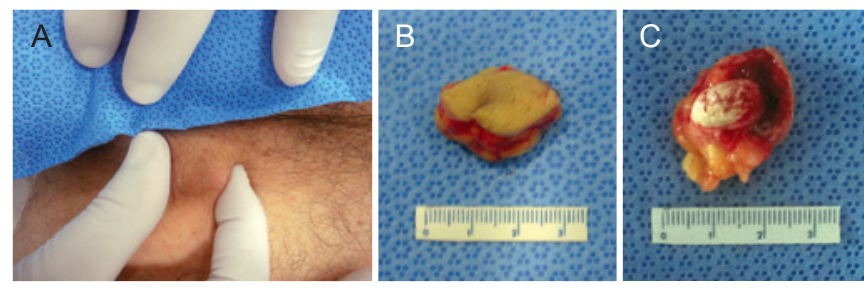

Figure 4 - Case 7, male, 70 years of age, lesion in left inguinocrural area. In $\boldsymbol{A}$, pinching the lesion evidencing adhesion to overlying skin. In $\boldsymbol{B}$, the surgical specimen with inclusion of overlying skin. In $\boldsymbol{C}$, the surgical specimen showing the calcified lesion.

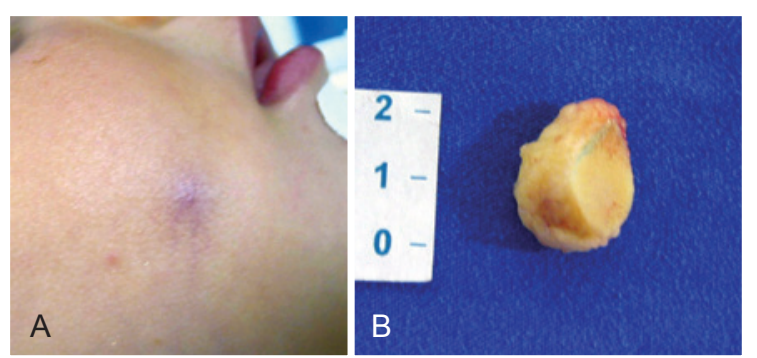

Figure 5 - Case 20, female, 1 year of age, lesion on right cheek. In $\boldsymbol{A}$, bluish lesion. In $\boldsymbol{B}$, the surgical specimen with the inclusion of the overlying skin. 


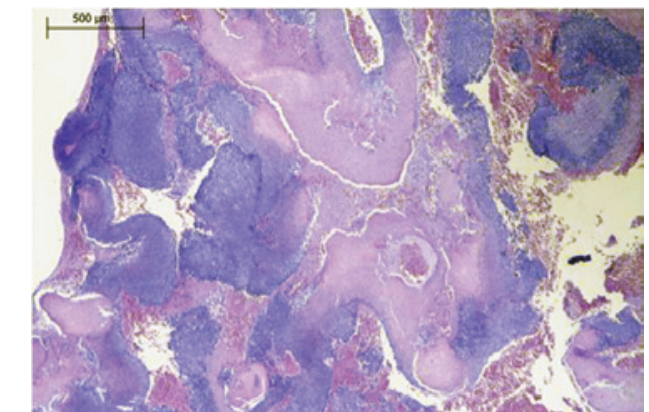

Figure 6 - Pilomatricoma. The tumor consists of peripheral islands of basaloid and ghost cells seen in the center of the field.

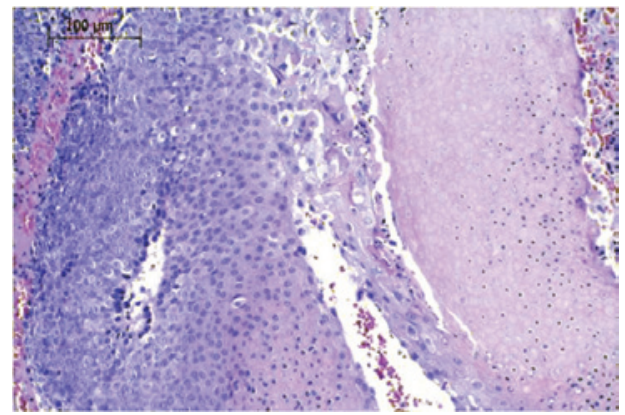

Figure 7 -Pilomatricoma. Islands of basaloid cells on the left and ghost cells on the right.

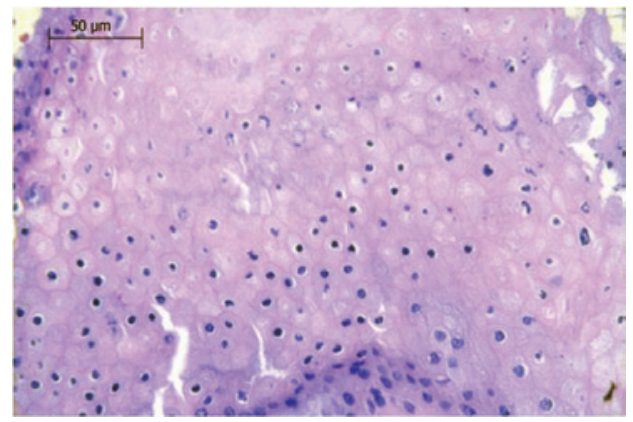

Figure 8 -Pilomatricoma. The evolution of basaloid cells into shadow cells is characterized by the loss of nuclei.

\section{DISCUSSION}

According to Hashimoto et al. ${ }^{5}$, pilomatricoma is a tumor derived from the primitive basal cells of the epidermis that differentiate into hair matrix cells. The lesion is currently described as a benign skin appendage tumor.

Moehlenbeck ${ }^{9}$ reviewed 140,000 cases of skin tumors and noted that pilomatricoma accounted for $0.1 \%$ of all cases. The lesions may develop at any age, but they occur predominantly in children and young adults ${ }^{10}$. They are the third most commonly excised mass in children, following epidermoid cysts and lymph node lesions. A total of $40 \%$ of the cases occur in patients who are under 10 years of age ${ }^{10}$. In the preset study, the patients were 1-71 years of age (mean, 26.5 years). The tumors developed predominantly in the first and second decades of life (59.3\% of the cases), with a peak incidence occurring before the age of 10 years - which confirms the findings of the literature.

A consensus regarding the sex preponderance of the disease, however, is nonexistent. Some studies show a slight female predominance ${ }^{9}$, whereas other studies indicate the opposite $^{6}$. In the present study, $55.4 \%$ of the patients were male and 25 (44.6) female, yielding a male:female ratio of 1.24:1.

The most common sites of involvement are the face and neck, followed by the upper extremities, the trunk, and the lower extremities ${ }^{8}$. The palms, soles, and genitalia are not affected ${ }^{6}$. The present study partially corroborates these data: $42.4 \%$ of the lesions occurred on the face, $19.7 \%$ on the upper limbs, $13.6 \%$ on the trunk, $12.1 \%$ on the lower limbs, $9,1 \%$ on the neck, and $3.1 \%$ on the scalp.

Most studies report lesions that are $0.5-3 \mathrm{~cm}$ in diameter $^{8,10,11}$. In the present study, the mean diameter was $0.6 \mathrm{~cm}$.

Histopathologically, pilomatricoma is characterized by islands of cells arranged in a circular configuration with nucleated basaloid cells in the periphery and anucleated shadow cells, also known as ghost cells, in the center. It is important to emphasize that ghost cells are not exclusive to pilomatricoma; in fact, they also occur in epidermoid cysts and in chronic dermatitis with hyperkeratosis ${ }^{3}$.

Although being unknown, the etiopathogenesis of the condition has been related to mutations in the CTNN $\beta 1$ gene, responsible for encoding $\beta$ catenin, which plays a role in normal hair development ${ }^{11}$. A recent study showed that trisomy 18 is a cytogenetic alteration in pilomatricoma ${ }^{12}$. Pilomatricoma may be associated with myotonic dystrophy (Steinert disease); Gardner, Turner, Rubinstein-Taybi, and Soto syndromes; 21-hidroxylase deficiency; trisomy 9; MYH polyposis; celiac disease; xeroderma pigmentosum; sarcoidosis; and angiomyxoma ${ }^{10}$. An association with chronic disease ${ }^{13}$ has not been documented, although there is a correlation with hypercalcemia and increased levels of the parathyroid hormone-related protein ${ }^{14}$. Pilomatricoma is not a hereditary condition, despite the presence of some cases of familial occurrence reported in the literature ${ }^{15}$.

Pilomatricoma is predominantly diagnosed by clinical examination ${ }^{16}$, which can be difficult. The rate of accurate preoperative diagnosis ranged from $0 \%$ to $30 \%$ due to the variety of potential conditions included in the differential diagnoses, such as dermoid cysts, epidermoid cysts, branchial cysts, lipomas, preauricular sinuses, adenopathies, hemangiomas, and foreign body reaction ${ }^{4}$. In the present study, 
the surgeon suspected the correct clinical diagnosis in $19.7 \%$ of the cases, a value that is in accordance with that noted in the literature.

The most frequent erroneous diagnosis was carcinoma $(12.1 \%)$, followed by epidermoid cyst (9.1\%). Pilomatricoma may present with microcalcifications on mammography, mimicking breast cancer ${ }^{17}$. Imaging methods, such as ultrasonography and computed tomography, have limited utility and are specifically used to differentiate pre-auricular masses and parotid gland tumors or to evaluate aggressive lesions ${ }^{8}$. Fine-needle aspiration, in the presence of ghost cells, could make a correct diagnosis; however, the absence of them could lead to a false negative or even a misinterpretation of pilomatrix carcinoma ${ }^{11}$.

Multiple pilomatricomas are rare, accounting for about $24 \%$ of cases $^{9,10}$, and its known association with the cited genetic disorders ${ }^{10}$ should give rise to an extense propedeutic. In the present study, a female patient presented with 8 lesions that were excised from the face $(n=4)$, trunk $(n=3)$, and lower $\operatorname{limb}(\mathrm{n}=1)$ at $5,7,9,11$, and 14 years of age. This case of multiple pilomatricoma represents $1.8 \%$ of all cases, a finding that is in accordance with the literature. Such patient had the clinical diagnosis of Kabuki Syndrome, a rare multiple congenital anomalies/mental retardation syndrome of unknown cause ${ }^{18}$.

Recurrence following surgical treatment is rare, with an overall rate of $2-6 \%{ }^{11,19}$. Recurrences should raise the surgeon's suspicion of pilomatrixoma carcinoma, a malignant variant of pilomatricoma. Warning signs that should be considered are as follows: older age and male gender, fast lesion growth, adherence to adjacent structures, skin infiltration, ill-defined margins, capsular tissue infiltration, high mitotic activity, atypia, central necrosis, and lymphatic vascular changes ${ }^{6,13,19}$. The most common sites of metastases include the lungs, bones, brain, abdominal organs, skin, and lymph nodes ${ }^{20}$. In the present study, a patient $(1.8 \%)$ presented with lesion recurrence 3 months after the operation. A 43-year-old man with a lesion on the trunk was diagnosed with proliferating pilomatricoma. An anatomopathological examination showed atypical cells with hypertrophic nuclei and multiple mitotic figures. However, the lesion was relatively symmetric with regularly shaped basaloid lobules and no perineural or lymphatic involvement, revealing a benign entity. In fact, there is no evidence in the literature that this variant is a precursor of malignant pilomatricoma ${ }^{19}$.

The recommended treatment is the complete surgical excision of the lesion since spontaneous regression has not yet been observed. The use of $1-\mathrm{cm}$ lateral margins in the excision is essential to minimize local recurrence. The skin overlying the tumor should be included in the excision because the tumor adheres to the dermis ${ }^{13}$.

\section{CONCLUSIONS}

Pilomatricomas constitute a benign skin appendage tumor, derived from primitive basal cells of epidermis that differentiate as hair matrix cells, and represent a relatively rare affection, being most frequently observed among children.

The diagnosis is eminently clinical and medical images are generally not required, unless the symptoms or lesion location warrant such diagnostic assessments.

The treatment of choice is complete surgical excision, with resection lateral margins of $1 \mathrm{~cm}$. Recurrence rate, as well as multiple or malignant variants, is low.

Considering that pilomatricoma is frequently misdiagnosed, it should be considered with other benign or malignant conditions in the clinical differential diagnosis of solitary firm skin nodules, especially those on head, neck or upper limbs.

Therefore, careful clinical examination and familiarity with the condition may lead to accurate diagnosis and appropriate treatment.

\section{REFERENCES}

1. Malherbe A, Chenantais J. Note sur l'epitheliome calcifié des glandes sebacées. Prog Med. 1880;8:826-37.

2. Dubreuilh W, Cazenave E. De l'épitheliome calcifié: étude histologique. Ann Dermatol Syphilol. 1922;3:257-68.

3. Forbis R Jr, Helwig EB. Pilomatrixoma (calcifying epithelioma). Arch Dermatol. 1961;83:606-18.

4. Arnold HL Jr. Pilomatrixoma. Arch Dermatol. 1974;109(5):736.

5. Hashimoto K, Nelson RG, Lever WF. Calcifying epithelioma of Malherbe. Histochemical and electron microscopic studies. J Invest Dermatol. 1966;46(4):391-408.

6. Guinot-Moya R, Valmaseda-Castellon E, Berini-Aytes L, Gay-Escoda C. Pilomatrixoma: review of 205 cases. Med Oral Patol Oral Cir Bucal. 2011;16(4):e552-5.

7. Solivetti FM, Elia F, Drusco A, Panetta C, Amantea A, Di Carlo A. Epithelioma of Malherbe: new ultrasound patterns. J Exp Clin Cancer Res. 2010;6:29-42.

8. Lan MY, Lan MC, Ho CY, Li WY, Lin CZ. Pilomatricoma of the head and neck: a retrospective review of 179 cases. Arch Otolaryngol Head Neck Surg. 2003;129(12):1327-30.

9. Moehlenbeck FW. Pilomatrixoma (calcifying ephitelioma). A statistical study. Arch Dermatol. 1973;108(4):532-4.

10. Yencha MW. Head and neck pilomatricoma in the pediatric age group: a retrospective study and literature review. Int J Pediatr Otorhinolaryngol. 2001;57(2):123-8.

11. Thomas RW, Perkins JA, Ruegemer JL, Munaretto JA. Surgical excision of pilomatrixoma of the head and neck: a retrospective review of 26 cases. Ear Nose Throat J. 1999;78(8):541-8.

12. Agoston AT, Liang CW, Richkind KE, Fletcher JA, Vargas SO. Trisomy 18 is a consistent cytogenetic feature in pilomatricoma. Mod Pathol. 2010;23(8):1147-50.

13. Yoshimura Y, Obara S, Mikami T, Matsuda S. Calcifying epithelioma (pilomatrixoma) of the head and neck: analysis of 37 cases. Br J Oral Maxillofac Surg. 1997;35(6):429-32.

14. Kambe Y, Nakano H, Kaneko T, Aizu T, Ikenaga S, Harada K, et al. Giant pilomatricoma associated with hypercalcaemia and elevated levels of parathyroid hormone-related protein. Br J Dermatol. 2006;155(1):208-10. 
15. Papadavid E, Mistidou M, Katoulis A, Zambacos G, Stavrianeas N, Panayiotides J, et al. Familial occurrence of calcifying epithelioma of Malherbe. Int J Dermatol. 2010;49(12):1456-7.

16. Baltogiannis N, Faviou E, Cigliano B, D'Agostino S. Diagnosis of pilomatrixoma in childhood. Plast Reconstr Surg. 2005;115(6):1783.

17. Rousselot C, Tourasse C, Samimi M, Degand P, Dénier JF, Michenet P. Breast pilomatrixoma manifested as microcalcifications on mammography: report of two cases. J Radiol. 2007;88(7-8 Pt 1):978-80.
18. Adam MP, Hudgins L. Kabuki syndrome: a review. Clin Genet. 2005; 67(3):209-19.

19. Brenn T, McKee PH. Tumors of the hair follicle. In: McKee PH, Calonje E, Granter SR, eds. Pathology of the skin. $3^{\text {rd }}$ ed. Philadelphia: Elsevier; 2005. p.1536-9.

20. Autelitano L, Biglioli F, Migliori G, Colletti G. Pilomatrix carcinoma with visceral metastases: case report and review of the literature. J Plast Reconstr Aesthet Surg. 2009;62(12):e574-7.

\section{Correspondence to:}

Rebeca Paohwa Liu da Fonseca

Rua Dionísio Cerqueira, 42 - ap. 301 - Gutierrez - Belo Horizonte, MG, Brazil - CEP 30430-140

E-mail: rebeca_liu@hotmail.com 